\title{
Factor Analysis of Smart Social Media Technology to Promote Professional Learning Communities for Teachers
}

\author{
https://doi.org/10.3991/ijim.v14i20.17253 \\ Kemmanat Mingsiritham, Gan Chanyawudhiwan $(\bowtie)$ \\ Sukhothai Thammathirat Open University, Nonthaburi, Thailand \\ ganechay@gmail.com \\ Chaiyos Paiwithayasiritham \\ Silpakorn University, Nakhon Pathom, Thailand
}

\begin{abstract}
Professional learning of teachers is of great importance for the development of educational quality. The cooperation of teachers in the professional learning community can lead to effectiveness in professional development. At present, technology plays an important role in making professional learning more successful. In particular, smart technology is used for the quantitative and qualitative analysis of the target audience which helps teachers plan their work. Smart technology can be operated and controlled smartly. A learning system with a database system acts as a central body of knowledge that supports virtual learning. This makes learning and transferring and extending knowledge in the virtual learning community more convenient. Smart social media technology to promote professional learning communities for teachers consisted of 7 components: 1) professional learning communities for teacher, 2) cloud technology, 3) augmented reality, 4) internet of thing, 5) social technology, 6) data analytics technology, and 7) mobile technology.
\end{abstract}

Keywords-Smart technology, Social media, Professional learning communities

\section{Introduction}

The rapidly changing society and knowledge has led to a focus on teacher development to prepare learners for education in the 21 st century [1]. This means that teachers and school administrators must keep pace with the constant changes in their professional knowledge [2]. High-quality and ongoing professional learning requires constant review of one's own performance and improvement through work and collaborative learning [3]. Teacher collaborative learning is facilitated by technology, especially social media which is widely used through various devices, such as smartphones, computers, and tablets. If social media is applied to analyze problems and predict the needs of teachers and learners, it will help to develop professional knowledge of teachers effectively. Professional teamwork and teacher networks can 
contribute to an improvement of teaching and learning. The new challenge, therefore, is to expand network cooperation outside the school [4]. Such an approach makes it possible to simplify the work of the teacher, extend the learning time for students due to extracurricular time, and implement the "Anytime Anywhere Learning" [5]. Based on advanced technology and the importance of the professional learning community mentioned above, the researcher is interested in conducting factor analysis of smart social media technology to promote professional learning communities for teachers to apply the results to further develop quality learning.

\section{Review of the Literature}

Professional Learning Community (PLC) is a process of creating changes through learning from group performance. The community consists of teachers who come to work together and support each other with the objective to improve learning. The community jointly plans learning goals and reflects learning outcomes, both personal performance and overall results. The cooperation occurs through exchanging learning process, criticism, collaborative work by focusing on and promoting a holistic learning process [6], [7]. The PLC process consists of 6 steps. 1) Building a team of teachers to create knowledge and understanding for teachers and related persons. This is done by sharing experiences using professional models as motivation and the driving force of changes. 2) Planning for success. This step is to identify problems arising in the classroom, set a target, subject, or issue relating to the problem, and finding a solution. The focus is mainly on the development of learners. 3) Taking action according to planned activities. 4) Observing performance by recording and collecting information in various forms planned. 5) Reflecting. After gaining observing information, teachers will have a discussion with positive communication to generate comments and suggestions for improvement and development of teaching and learning management. 6) Learning and professional development. This is the stage where the group gathers information and presents the learning outcomes to others. The results may be presented as an innovation or development method used to develop learners to expand and complement group learning.

\subsection{Smart social media technology}

The development of teachers' PLCs is changing according to the global connected society. Academic advancement and the evolution of information and communication technology deliver exponential volumes of discovered and generated knowledge. Newly created knowledge has been spread across the world without boundaries. Accessible knowledge and convenient communication have become basic knowledge that can be developed into new knowledge or proven repeatedly. The technology that can be employed to foster the development of the professional learning community is associated with smart communication that can build a learning community to create interaction. Smart technology enables the community to be accessible from a wide variety of devices anytime and anywhere. The technology can analyze in-depth data 
to help to make decisions, store information and contents in multiple devices and use information from cloud storage. This is based on the concept of learning management design that focuses on learner experience based on 6 smart social networking technologies.

Social technology plays an important role in exchanging information by means of interaction through computer networks that share and exchange information resources. It is a tool that helps support collaborative learning to develop knowledge. It allows students to express their opinions in an interactive way, exchange ideas for problem solving, and create new knowledge [8].

Mobile technology promotes boundless learning. Communication technology allows everyone to communicate and access information without limits anywhere and anytime through wireless networks and portable devices. [9], [10].

Internet of thing is a tool for communication that can reach most things in the world. Many organizations choose to use this effective communication system. Internet of thing has been used in many ways. The internet which has been used to increase efficiency is a tool to support learning and communication, resulting in new processes and services that meet the needs [11], [12].

Cloud technology is similar to a data warehouse with enormous storage capacity. It provides various types of online information services without limits which makes data quickly and easily accessible. It is a tool that creates effective knowledge management because of its flexible features. It increases learning opportunities and increase the efficiency of teaching and learning and the transfer of knowledge. [13], [14]

Data analytics is a valuable knowledge resource. It will be very useful if knowledge is in the form ready to be processed using technology or instruction sets and models. The information obtained from the analysis and interpretation can be used to improve operation and create advantages and opportunities based on the information generated [15].

Augmented reality is the technology that has the potential to develop many areas of work. It can be used to improve learning management to create new learning experiences and promote successful learning, comparing to the instruction without using virtual media [16], a technology which fuses virtual materials into a real-time situation or augments the reality to facilitate teaching and learning [17].

The 6 smart social network technologies that promote professional learning communities for teachers can create a learning system that stores knowledge by linking with a central knowledge system. Technology can create a learning system in the virtual world and can analyze various statistical data to solves problems. This is in line with the digital 4.0 era which aims to expand professional learning opportunities to be inclusive and equitable. 


\section{$3 \quad$ Research Methodology}

\subsection{Design}

The researcher used exploratory factor analysis to obtain the information on smart social media technology to promote professional learning communities for teachers. The researcher analyzed related conceptual theories and research. Then, confirmatory factor analysis was conducted to confirm the components of smart social media technology to promote professional learning communities for teachers with empirical data.

\subsection{Research sample}

Teachers in the basic education level employed a sample group of 900 basic education teachers obtained by Simple Random Sampling method which was divided into exploratory factor analysis (EFA) and confirmatory factor analysis (CFA), 450 each (from determining the sample size of the variable with the ratio of 1 variable to 5 people. In factor analysis [18], the researcher set 89 variables, therefore setting 900 people as a sample group).

\subsection{Research instruments}

The researcher used two questionnaires to study the opinions about PLC components and process by using smart social media technology. The first questionnaire was for exploratory factor analysis and the second questionnaire was for confirmatory factor analysis. Each questionnaire was divided into 2 parts: Part 1 was the general information of teachers, such as gender, age, education, academic standing, workplace, and teaching experience. Part 2 was the components of smart social media technology and professional learning communities obtained from the study of related concepts, theory, and research in the form of 5 levels of the rating scale. The questionnaire passed content validation from 5 experts and tryout with 30 basic education teachers to verify the reliability by using the Cronbach's Alpha coefficient formula, equal to .987 and .965 respectively.

\subsection{Research method}

The researcher sent the online questionnaire to the sample group, then collected data and selected questionnaires that were completely answered to analyze the data.

\subsection{Data analysis}

Data analysis used descriptive statistics such as frequency, percentage, mean, standard deviation, and factor analysis by exploratory factor analysis and confirmatory factor analysis by using a software program. 


\section{$4 \quad$ Research Findings}

\subsection{Results of exploratory factor analysis (EFA)}

Results of an exploratory factor analysis of the smart social media technology and professional learning communities for teachers by considering the Eigen Value of 1.00 and above found that there were 9 components, which can be the components of smart social media technology and professional learning communities at $74.30 \%$. However, when considering the component with a loading value more than .30 and has at least 3 variables, it was found that there were 7 components of the smart social media technology and professional learning communities for teachers as shown in Table 1 .

Table 1. Results of Exploratory Factor Analysis (EFA)

\begin{tabular}{|c|c|c|c|c|l|}
\hline Factor & $\begin{array}{c}\text { Number of } \\
\text { variances }\end{array}$ & $\begin{array}{c}\text { Number of } \\
\text { variables }\end{array}$ & $\begin{array}{c}\text { Eigen } \\
\text { value }\end{array}$ & $\begin{array}{c}\text { Percent of } \\
\text { variance }\end{array}$ & \multicolumn{1}{|c|}{ Factor name } \\
\hline 1 & 38 & $52-89$ & 43.17 & 48.51 & Professional Learning Communities (PLC) \\
\hline 2 & 9 & $28-36$ & 7.99 & 8.98 & Cloud Technology (CT) \\
\hline 3 & 8 & $44-51$ & 4.73 & 5.31 & Augmented Reality (AR) \\
\hline 4 & 9 & $19-27$ & 2.55 & 2.87 & Internet of Thing (IoT) \\
\hline 5 & 11 & $1-11$ & 1.85 & 2.08 & Social Technology (ST) \\
\hline 6 & 7 & $37-43$ & 1.69 & 1.90 & Data Analytics Technology (DAT) \\
\hline 7 & 5 & $14-18$ & 1.55 & 1.74 & Mobile Technology (MT) \\
\hline
\end{tabular}

\subsection{Results of confirmatory factor analysis (CFA)}

After conducting the confirmatory factor analysis, the researcher collected data from 450 people to confirm the accuracy of the components. The results of the confirmatory factor analysis of the smart social media technology and professional learning communities for teachers (SMPLC) found that the model was consistent with the empirical data, which can be determined from the chi-square $\left(=6.17, \mathrm{df}=6, \mathrm{p}=\chi^{2}\right.$ 0.405 ) which is not significantly different from zero. The value of the goodness of fit index (GFI) was .996; the Adjusted Goodness of Fit Index (AGFI) was .984 and the root mean square residual (RMR) was equal to .004. The results of the analysis showed that the model was consistent with empirical data. The components of smart social media technology and the professional learning communities for teachers consisted of 7 components.

The component weight value of the standard score (B) of all variables was positive with sizes between .700 and .942 . When considering the component weight (b) of variables, it was found that the component weight of all manifest variables had statistical significance at .01 levels. The variable with the highest important weight value was Cloud technology (CT) with the standard component weight equal to .942 and the common variation with smart social media technology and professional learning communities for teachers at $88.8 \%$, followed by mobile technology (MT) with the standard component weight equal to. 823 and the common variation with smart social 
media technology and professional learning communities for teachers at $67.8 \%$. The variable with the least standard component weight was the augmented reality (AR) with the standard component weight equal to .700 and the common variation with smart social media technology and professional learning communities for teachers at 49.0\%. This showed that these variables were important variables of smart social media technology and professional learning communities for teachers (SMPLC) as shown in Table 2 and Figure 1.

Table 2. Analysis results of the components of smart social media technology and professional learning communities for teachers (SMPLC)

\begin{tabular}{|l|c|c|c|c|c|}
\hline \multicolumn{1}{|c|}{ Variances } & \multicolumn{2}{|c|}{ Component weight } & $\mathbf{t}$ & $\mathbf{R}^{\mathbf{2}}$ & $\begin{array}{c}\text { Coefficient } \\
\text { Scores }\end{array}$ \\
\hline & $\boldsymbol{b}(\boldsymbol{S E})$ & $\boldsymbol{B}$ & & & Component \\
\hline PLC & $.437(.023)$ & .795 & $18.772 * *$ & .632 & .518 \\
\hline CT & $.685(.034)$ & .942 & $19.861 * *$ & .888 & .897 \\
\hline AR & $.498(.029)$ & .700 & $17.463 * *$ & .490 & -.142 \\
\hline IoT & $.364(.019)$ & .775 & $18.767 * *$ & .601 & .434 \\
\hline ST & $.374(.020)$ & .763 & $19.018^{*} *$ & .582 & .115 \\
\hline DAT & $.454(.025)$ & .720 & $18.039 * *$ & .519 & -.196 \\
\hline MT & $.518(.025)$ & .823 & $20.566 * *$ & .678 & .454 \\
\hline \multicolumn{7}{|l|}{ Chi-square $=6.17, \mathrm{df}=6, \mathrm{P}-\mathrm{value}=.405, \mathrm{GFI}=.996, \mathrm{AGFI}=.984, \mathrm{RMR}=.004, \mathrm{RMSEA}=.007$} \\
\hline
\end{tabular}

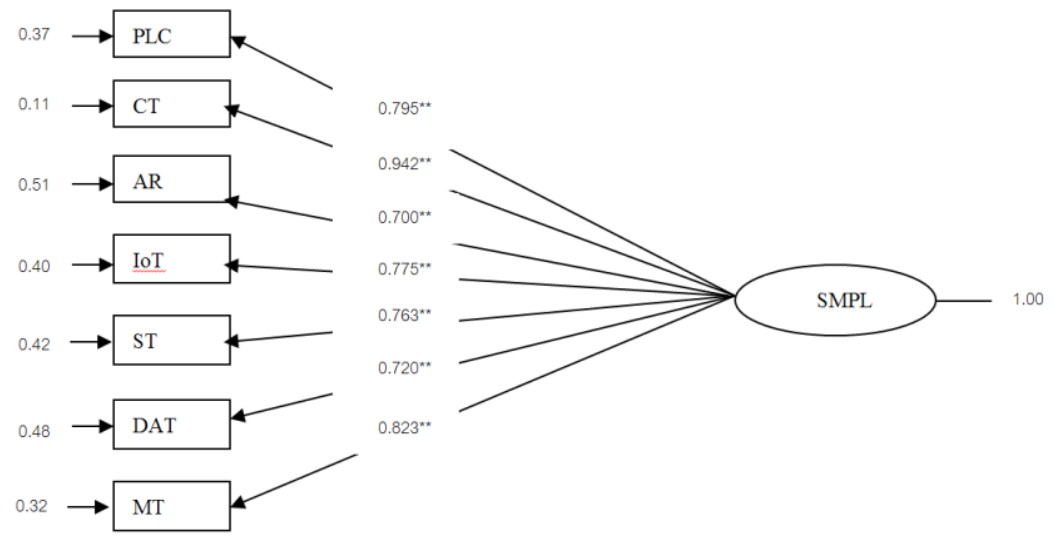

Chi-square $=6.17, \mathrm{df}=6, \mathrm{P}$-value $=.405, \mathrm{GFI}=.996, \mathrm{AGFI}=.984, \mathrm{RMR}=.004, \mathrm{RMSEA}=.007$

Fig. 1. Analysis results of the components of smart social media technology and professional learning communities for teachers (SMPLC)

\section{$5 \quad$ Discussion and Conclusion}

The 6 smart social media technologies to promote professional learning communities for teachers can create a learning system that collects knowledge by connecting with a central knowledge database system. The technologies can create a learning 
system in the smart virtual world and can analyze statistical data that leads to a solution. This is in accordance with the concept of effective social media communication which is open and engaging, resulting in the creation of connections and communities [19], [20] has considered the relationship between teacher agency and professional learning. There has been growing interest in professional learning communities as resources for professional learning. Connections have been made between professional learning communities and teacher agency, with professional learning communities seen as an affordance for the exercise of teacher agency. It was found that teachers had a positive attitude towards technology in PLC development. This was probably because technology helped teachers to solve problems that have occurred repeatedly. It explained trends in new situations and facilitated teachers to plan and develop teaching strategies in accordance with the changing context. Teachers must have a positive attitude towards accepting the changes and have the common goal of improving learner achievement. According to [21], the unique characteristics of smart mobile devices have the great potential to enrich the teaching and learning experience that the successful pedagogical use of technology depends on teachers' attitudes and acceptance towards technology. Teachers tend to develop themselves positively, especially when acquiring different knowledge and skills from external networks, enabling them to learn working methods and process in other schools, resulting in a better professional attitude [22].

\section{Acknowledgement}

This research was funded by Edtechfund, Ministry of Education

\section{$7 \quad$ References}

[1] Schleicher, A. (2012). Preparing teachers and developing school leaders for the 21 st century: Lessons from around the world. Paris, France: OECD Publishing. https://doi.org/10. $\underline{1787 / 9789264174559-e n}$

[2] Vescio, V., Ross, D., \& Adams, A. (2008). A review of research on the impact of professional learning communities on teaching practice and student learning. Teaching and Teacher Education Journal. 24(1), 80-91 pp. https://doi.org/10.1016/j.tate.2007.01.004

[3] Chapman, C., \& Muijs, D. (2014). Does school-to-school collaboration promote school improvement? A study of the impact of school federations on student outcomes. School Effectiveness and School Improvement. 25(3), 351-393 pp. https://doi.org/10.1080/092434 $\underline{53.2013 .840319}$

[4] Lomos, C., Hofman, R. H., \& Bosker, R. J. (2011). Professional communities and student achievement-A meta-analysis. School Effectiveness and School Improvement. 22(2), 121-148 pp. https://doi.org/10.1080/09243453.2010.550467

[5] Maslova, I., Burdina, G., \& Krapotkina, I. (2020). The use of electronic educational resources and innovative educational technologies in University Education. International Journal of Emerging Technologies in Learning (iJET). 15(6), 68-79 pp. https://doi.org/10. 3991/ijet.v15i16.14909 
Robert, H. V. \& Chrispeels, J. H. (2017). Understanding the link between professional learning communities and teacher collective efficacy. An International Journal of Research, Policy and Practice. 28(5), 1-12 pp. https://doi.org/10.1080/09243453.2017. $\underline{1299015}$

[6] Distance Learning Foundation Under the Royal Patronage. (2013). E-Learning Content Production Project of Distance Learning via Satellite. 26 September 2013. http://edltv.thai. net/index.php?mod=Message \&op=aboutus

[7] Raktham, T. (2016). Trends for hotel technology in 2017. Retrieved March 15, 2017, from https://smartfinder.asia/th/hotel-technology-trend-2017/

[8] Polkacha. P , Saelee, S \& Sintanakul, K. (2016). Development of Think Pair Share Learning System Using Mobile Learning. Journal of Roi Et Rajabhat University.(2)10 (July December 2016), 72-79 pp.

[9] Boonpan, A., Wongsim, M. \& Posri, W. .(2018) Internet Technology Capability on Performance of Telecommunication Business in Thailand. MBA-KKU Journal.11(2) (July December 2018), 142-160 pp.

[10] Wongwattanasin, K \& Charmonman, S. (2012). Vision in Internet Technology. Phranakhon Si Ayutthaya Rejabhat University Research Journal. 12 (12), 1 - 5 pp.

[11] Grace, T., \& Mell, P. (2011). The NIST Definition of Cloud Computing: Recommendations of the National Institute of Standards and Technology. NIST Special Publication. $135-145 \mathrm{pp}$.

[12] Denton, D. W. (2012). Enhancing instruction through constructivism, cooperative learning, and cloud computing. TechTrends. 56(4), 34-41 pp. https://doi.org/10.1007/s11528-012-05 $\underline{85-1}$

[13] Bora, U. J., \& Ahmed, M. (2013). E-learning using cloud computing. International Journal of Science and Modern Engineering. 1(2), 9-12 pp.

[14] Mark, B. M. \& Dunser, A. (2012). Augmented Reality in the Classroom. IEEE Computer Society. (Online), 56-60 pp.

[15] Boyd, D. (2008). Taken out of context. Doctoral Thesis. University of California, Berkeley.

[16] Saundarajan, K., Osman, S., \& Daud, M. F. (2020). Learning algebra using augmented reality a preliminary investigation on the application of photomath for lower secondary education. International. vestigation on the application of photomath for lower secondary education. International. https://doi.org/10.3991/ijet.v15i16.10540

[17] Journal of Emerging Technologies in Learning (iJET). 15(16), 123- 133 pp. https://doi.org/ $\underline{10.3991 / i j e t . v 15 i 16.10540}$

[18] Wongwanich, S \& Wiratchai.N. (2003). Thesis Counseling Guidelines .B: Center for Textbooks and Academic Documents, Faculty of Education, Chulalongkorn University.

[19] Philpott, C. \& Oates, C. (2016). Teacher agency and professional learning communities; what can Learning Rounds in Scotland teach us? Professional Development in Education Journal. 43(3), 318-333 pp. https://doi.org/10.1080/19415257.2016.1180316

[20] Kob, C. G., Kannapiran, S., \& Shah, A. (2020). The Usage of Mobile Learning: Comparative Studies among Technical and Vocational Education Students in Selected Universities. International Journal of Interactive Mobile Technologies (iJIM). 14(05), 203- 209 pp. https ://doi.org/10.3991/ijim.v14i05.13355

[21] Papadakis, S. (2018). Evaluating pre-service teachers' acceptance of mobile devices with regards to their age and gender: a case study in Greece. International Journal of Mobile Learning and Organisation. 12(4), 336-352 pp. https://doi.org/10.1504/IJMLO.2018.09513 0 https://doi.org/10.1504/ijmlo.2018.10013372 
[22] Prenger, R., Poortman, C. L., \& Handelzalts, A. (2019). The effects of networked professional learning communities. Journal of teacher education. 70(5), 441-452 pp. https://doi. org/10.1177/0022487117753574

\section{Authors}

Kemmanat Mingsiritham is an Associate Professor at the Office of Educational Technology, Sukhothai Thammathirat Open University, Nonthaburi 11120 Thailand. Research interests include Instructonal Design, Virtual Learning Design, and Distance Learning. (kemmanat.min@stou.ac.th)

Gan Chanyawudhiwan is an Assistant Professor at the Office of Educational Technology, Sukhothai Thammathirat Open University, Nonthaburi 11120 Thailand. Research interests include Instructional Design, Learning Design, Universal Design, User Experience (UX) Design, User Interface (UI) Design and Human-computer interaction (HCI). (ganechay@gmail.com)

Chaiyos Paiwithayasiritham is an Associate Professor at the Faculty of Education, Silpakorn University, Nakhon Pathom 73000 Thailand. Research interests include Research Synthesis, Needs Assessment, Educational Measurement and Evaluation and Educational Research. (paiwithayasirit_c@su.ac.th)

Article submitted 2020-07-24. Resubmitted 2020-09-11. Final acceptance 2020-09-11. Final version published as submitted by the authors. 